\title{
Pengelolaan Pariwisata Berbasis Pemberdayaan Masyarakat (Studi Kasus Desa Sawentar)
}

\author{
Nurfi Fuadi Laksono ${ }^{(1)}$ Anif Fatma Chawa ${ }^{(2)}$, Yayuk Yuliati ${ }^{(3)}$ \\ ${ }^{1,2}$ Fakultas Ilmu Sosial Dan Politik Universitas Brawijaya, Indonesia \\ ${ }^{3}$ Fakultas Pertanian Universitas Brawijaya, Indonesia
}

Email: ${ }^{1}$ laksonofuadinurfi@gmail.com, ${ }^{2}$ anif.chawa@gmail.com,

${ }^{3}$ yayuk.yyl@gmail.com

\begin{tabular}{l}
\hline Tersedia Online di \\
\hline http://www.jurnal.unublitar.ac.id/i \\
ndex.php/briliant
\end{tabular}

Sejarah Artikel

Diterima pada 22 Agustus 2020

Disetujui pada 22 September 2020

Dipublikasikan pada 30 November 2020

Hal. $865-878$

\section{Kata Kunci:}

Pemberdayaan Masyarakat, Partisipasi Masyarakat,Wisata

Edukatif, Desa Sawentar.

\section{DOI:}

http://dx.doi.org/10.28926/briliant. v3i4.539

\begin{abstract}
Abstrak: Penelitian ini bertujuan untuk menganalisis pengelolaan pariwisata oleh pemerintah Desa Sawentar, hambatanhambatannya, serta mengajukan strategi pengembangan pariwisata berbasis permberdayaan masyarakat di Desa Sawentar. Penelitian ini bertolak dari strategi pengembangan pariwisata di Desa Sawentar yang bersifat top-down, terbatas pada momentum dan terfokus warisan budaya atau sejarah bendawi, tanpa kemitraan sinergis, serta minim partisipasi masyarakat. Penelitian ini menggunakan pendekatan kualitatif dengan metode studi kasus. Pengumpulan data dilakukan melalui wawancara mendalam dan observasi partisipasi. Analisis data dilakukan secara deskriptif, dengan bertolak dari konsep Pemberdayaan Masyarakat 5P Menurut Suharto dan teori Partisipasi Sherry Arnstein.Hasil penelitian menunjukkan pengelolaan pariwisata yang oleh pemerintah Desa Sawentar dilakukan melalui peletarian tradisi budaya dan pelatihan pengelolaan homestay. Adapun hambatan-
\end{abstract} hambatan yang dialami berupa tidak ada pemetaan potensi pariwisata strategis, tidak adanya pembinaan organisasi POKDARWIS Lwang Wentar, kurangnya alur komunikasi dengan mitra kerja, serta adanya konflik antar organisasi. Dari hasil penelitian tersebut model pengembangan pariwisata berbasis masyarakat di Desa Sawentar yang ditawarkan yakni melalui pengembangan pariwisata edukasi.

\section{PENDAHULUAN}

Kegiatan wisata merupakan serangkaian aktivitas yang mencakup totalitas produksi (oleh penyedia) maupun konsumsi (oleh pengguna) barang dan jasa dengan maksud utama untuk rekreasi (Damanik, 2017). Konsep pariwisata tidak hanya berkaitan dengan keindahan panorama alam dan jelajah situs bersejarah, melainkan telah berkembang dengan melibatkan masyarakat dalam penataan pariwisata, melalui konsep wisata berbasis masyarakat. Berbagai produk pariwisata tersebut yang kemudian akan dinikmati oleh para konsumen dengan membelanjankan sejumlah uang.

Penerapan pariwisata berbasis masyarakat merupakan salah satu bentuk pemanfaatan sumber daya manusia dalam melatih kemandirian dan mengelola sumber daya yang dimiliki guna menunjang kesejahteraan masyarakat di sekitar wilayah destinasi wisata. Untuk itu diperlukan adanya upaya pemberdayaan masyarakat. Pemberdayaan masyarakat tidak hanya terbatas pada sifat ekonomis, 
namun juga bersifat politis (Friedman, 1992). Paradigma pemberdayaan bertujuan untuk merubah kondisi yang sentralistik menuju kondisi otonom, yang memberikan kesempatan kepada masyarakat untuk melaksanakan dan memanfaatkan program-progam pengembangan dan pembangunan secara mandiri, aktif dan proaktif, sehingga masyarakat memiliki posisi tawar (bargaining position) tertentu.

Pembangunan yang ideal dimulai dari kondisi di mana masyarakat berada dan dari apa yang dimiliki masyarakat. Paradigma pembangunan ini menitik beratkan pembangunan yang berpusat pada rakyat melalui partisipasi. Partisipasi adalah proses pemberian peran kepada individu sebagai aktor yang menetapkan tujuan, mengendalikan sumber daya dan mengarahkan proses yang mempengaruhi kehidupannya. Dengan kata lain, partisipasi memungkinkan masyarakat dalam menyelesaikan permasalan yang dihadapi secara mandiri. Dalam perspektif komunikasi, partisipasi menciptakan lingkungan umpan balik arus informasi tentang sikap, aspirasi, kebutuhan, dan kondisi lokal yang ada. Dengan demikian, partisipasi memperluas wawasan penerima proyek pembangunan serta memperluas jangkauan pelayanan pemerintah kepada seluruh lapisan masyarakat, sehingga dapat menopang pembangunan yang menyediakan lingkungan kondusif baik bagi aktualisasi potensi manusia maupun pertumbuhan manusia.

Aktualisasi partisipasi terdiri dari berbagai derajat keterlibatan masyarakat. Oleh karena itu, dibutuhkan tipologi partisipasi untuk membantu memahami praktek dari proses pelibatan masyarakat, sampai sejauh mana upaya peningkatan partisipasi masyarakat serta menilai dan mengevaluasi keberhasilan kinerja dari pihak-pihak yang melakukan pelibatan masyarakat. Mendefinisikan tipologi dan strategi partisipasi, yang didasarkan pada distribusi kekuasaan antara masyarakat dengan badan pemerintah (Arnstein, 1969). Menurut Amstein, partisipasi masyarakat identik dengan kekuasaan masyarakat (citizen partisipation is citizen power).

Peraturan Pemerintah Republik Indonesia Nomor 50 tahun 2011 tentang Rencana Induk Pembangunan Kepariwisataan Nasional Tahun 2010-2025 menyebutkan bahwa pemberdayaan masyarakat merupakan upaya peningkatan kesadaran, kapasitas, akses, dan peran masyarakat, baik secara individu maupun kelompok, dalam memajukan kualitas hidup, kemandirian, dan kesejahteraan melalui kegiatan kepariwisataan. Landasan hukum tersebut mendorong aktualisasi pariwisata berbasis masyarakat melalui kelompok-kelompok masyarakat sadar wisata di tingkat daerah.

Kabupaten Blitar merupakan salah satu daerah yang memiliki potensi wisata yang menjanjikan, sehingga perlu pergerakan yang massif dalam mempromosikan pariwisata. Strategi pariwisata yang diinisiasi pemerintah Kabupaten Blitar setiap tahun meliputi kegiatan kirab budaya pada hari jadi Kabupaten Blitar, pemilihan Gus-Jeng yaitu ajang duta pariwisata Kabupaten Blitar, Festival Grebeg Lawang Wentar dan Kirab Pusaka Kabupaten Blitar. Melalui event ini, Pemerintah Kabupaten Blitar mengharapkan masyarakat dapat mengembangkan pariwisatanya secara berkelanjutan.

Strategi yang demikian tampak masih bersifat top-down, dilakukan secara parsial (tergantung pada momentum), terpusat pada kegiatan di tingkat Kabupaten dan dengan ragam bentuk atau produk pariwisata yang terbatas. Oleh karena itu, dibutuhkan pengembangan strategi pariwisata yang melibatkan masyarakat secara

866 BRILIANT: Jurnal Riset dan Konseptual Volume 5 Nomor 4, November 2020 
aktif dan berkelanjutan, dengan mengoptimalkan berbagai potensi pariwisata (sejarah, budaya dan edukasi) yang dinamis di tingkat-tingkat desa.

Desa Sawentar merupakan salah satu desa di Kabupaten Blitar yang mencoba mengembangkan pariwisata desa yang berbasis masyarakat. Hal ini dilakukan melalui pembentukan Kelompok Sadar Wisata sejak tahun 2016, yang diberi nama POKDARWIS Lwang Wentar. Wisata yang dikelola oleh POKDARWIS adalah pariwisata edukasi dan budaya, dengan memanfaatkan situs sejarah peradaban Majapahit berupa Candi Sawentar, Sanggar Batik Lawang Wentar, jaranan (kuda lumping), sinau aksara Jawa kuna, Macapat (tembang puisi Jawa), Tiban (festival pemanggil hujan), Festival Grebeg Lwang Wentar dan Kirab Pusaka Kabupaten Blitar, serta wisata kuliner 1001.

Secara potensi Desa Sawentar memiliki kekhasan lingkungan dan aktivitas masyarakat yang berpotensi untuk dijadikan pariwisata edukasi dan budaya, yang ditandai dengan keberagaman UMKM, aktivitas pertanian, serta berbagai bentuk kegiatan industri kreatif (seperti batu bata, batik, kerajinan kayu, dan lain-lain). Wisata tidak harus merujuk pada destinasi pariwisata yang bersifat bendawi (seperti Candi), dengan anggapan bahwa pariwisata budaya sebatas berbarti pelestarian peninggalan nenek moyang yang bersifat bendawi. Menjual wisata tidak harus dengan peninggalan bendawi, namun dengan budaya, kearifan lokal serta aktivitas keseharian masyarakat. Pengelolaan yang tepat pada kegiatan masyarakat ini dapat berwujud konservatif, sebab hasilnya dapat digunakan sebagai objek pengembangan pariwisata yang berkelanjutan di Desa Sawentar.

Dalam prakteknya, program-program pariwisata Desa Sawentar tersebut mengalami pasang surut, akibat tidak adanya pemetaan, perencanaan, materi dan jadwal yang jelas. Hal ini dipersulit dengan komunikasi yang tidak efektif antara POKDARWIS Lwang Wentar dengan masyarakat penyedia atau pengelola jasa pariwisata. Sementara itu, peran pemerintah daerah pun masih sekedar memberikan izin untuk mengelola tanpa ada pendampingan yang berkelanjutan. Oleh karena itu, kehadiran POKDARWIS Lawang Wentar, dengan beberapa program yang berbasis budaya dan edukasi pengelolaan pariwisata di desa Sawentar, perlu dikembangkan melalui strategi pariwisata yang tertata secara sinergis.

Pengembangan strategi pariwisata yang sinergis ini penting, sebab dalam prakteknya, gagasan tentang fokus pengembangan pariwisata antara Pemerintah Desa Sawentar dan POKDARWIS tidak menemukan titik temu. Fokus wisata yang diinginkan oleh Pemerintah Desa Sawentar adalah event kebudayaan, sedangkan POKDARWIS Lwang Wentar lebih mengenalkan kearifan lokal masyarakat desa Sawentar. Akibatnya, potensi pariwisata di Desa Sawentar tidak dikembangkan secara terpadu dan tidak berjalan secara maksimal.

Pokok permasalahan tersebut mendorong kajian lebih lanjut dalam penelitian ini, yang berfokus pada tiga hal utama, yakni pengelolaan pariwisata oleh pemerintah Desa Sawentar, hambatan-hambatannya, serta mengajukan model pengembangan pariwisata berbasis permberdayaan masyarakat di Desa Sawentar. Dengan ketiga hal itu, diharapkan akan diperoleh gambaran kondisi pengelolaan pariwisata di Desa Sawentar untuk kemudian diajukan model pengembangan ke depannya. Model pengembangan pariwisata ini diharapkan mampu meningkatkan minat dan memberdayakan masyarakat dalam mengelola berbagai potensi dan 
sumber dayanya sehingga kegiatan pariwisata di Desa Sawentar dapat terasa manfaatnya secara optimal oleh masyarakat.

\section{METODE}

Penelitian ini menggunakan pendekatan kualitatif dengan metode studi kasus. Pendekatan kualitatif memungkinkan deskripsi yang lebih mendalam terhadap data dan analisis permasalahan yang diteliti guna membangun makna tertentu. Sementara itu, studi kasus dimaksudkan untuk memahami isu atau masalah yang spesifik guna memperoleh pemahaman mendalam tentang permasalahan tersebut.

Data utama yang digunakan dalam penelitian ini merupakan hasil wawancara mendalam peneliti dan informan, dengan di dukung oleh berbagai data lain sebagai pelengkap dan pendukung. Data pelengkap dan pendukung yang dimaksud mencakup hasil pengamatan langsung peneliti serta berbagai referensi pustaka yang relevan.

Teknik pengumpulan data yang digunakan dalam penelitian ini adalah observasi partisipasi dan wawancara mendalam. Observasi partisipasi dimaksudkan sebagai peran serta peneliti dalam kegiatan atau aktivitas informan sehari-hari guna mengamati dan mengumpulkan data penelitian secara valid. Adapun wawancara mendalam merupakan teknik pengumpulan data penelitian melalui dialog yang terarah antara peneliti dan infoman, dengan berpedoman pada pertanyaan-pertanyaan kunci penelitian.

Penentuan informan dalam penelitian ini dilakukan dengan pendekatan pourposive samping, dengan kriteria informan berupa terlibat langsung dalam kegiatan pemberdayaan, menangani program pemberdayaan, mampu menjelaskan fenomena yang diteliti dengan jelas, tepat, cermat dan relevan, serta bersedia dijadikan informan penelitian. Informan penelitian ini terdiri dari pelaku pariwisata, perangkat desa, tokoh adat atau budayawan, serta masyarakat Desa Sarwentar.

Proses pengumpulan data ini dilakukan secara terus menerus. Setelah data terkumpul, peneliti membuat analisi guna mencari makna tentatif yang akan secara terus menerus ditinjau kembali berdasarkan data yang diperoleh kemudian. Selanjutnya, peneliti melakukan verifikasi informasi untuk mendapatkan kebenaran dari data yang telah diperoleh dengan pendekatan triangulasi. Verifikasi ini akan terus dilakukan hingga sampai pada titik kejenuhan data penelitian dalam menjawabi permasalahan penelitian.

Teknik analisis data yang digunakan dalam penelitian ini adalah teknik deskriptif yang dilakukan melalui tiga alur kegiatan yaitu kondensasi, penyajian data dan penarikan kesimpulan (Miles \& Michael, 1992). Reduksi data dilakukan dengan pemilihan, pemusatan perhatian, penyederhanaan, pengabstrakan dan transformasi data kasar menjadi catatan-catatan tertulis di lapangan. Penyajian data dilakukan dengan uraian deskriptif untuk menyusun informasi yang kompleks ke dalam suatu bentuk yang sistematis untuk memperoleh pola-pola yang bermakna, serta memberikan kemungkinan untuk penarikan kesimpulan. Penarikan kesimpulan merupakan perumusan makna dari data yang telah diperoleh dan disajikan. Kesimpulan yang diambil dari data lapangan terus diuji kebenaran, kekokohan dan kecocokannya selama penelitian berlangsung, sehingga dapat benar-benar diperoleh kesimpulan yang obyektif dan terjamin validitasnya.

868 BRILIANT: Jurnal Riset dan Konseptual Volume 5 Nomor 4, November 2020 


\section{HASIL}

\section{1) Pengelolaan Pariwisata Oleh Pemerintah Desa Sawentar}

Pada tahun 2016, Desa Sawentar ditetapkan oleh Bupati Blitar sebagai desa budaya. Hal ini dilatarbelakangi oleh sikap gotong royong masyarakat yang dianggap sangat bagus, sebagai modal penting untuk pengembangan pariwisata budaya. Namun, pemerintah desa masih belum siap secara potensi untuk lingkungannya. Hal ini terlihat pada kegiatan hari jadi Sawentar (Grebeg Lwang Wentar) tahun 2016, yang bertepatan dengan pembentukan POKDARWIS Lwang Wentar. Oleh karena itu, sejak tahun 2016, pemerintah Desa Sawentar mulai secara aktif memberikan pengetahuan mengenai potensi pariwisata kepada masyarakat. Hal ini dianggap sebagai bentuk penguatan pemerintah desa kepada masyarakat, yakni penguatan kegiatan ekonomi untuk pariwisata, seperti menumbuh kembangkan UMKM serta menciptakan homestay.

Pada saat ini pemerintah desa dan masyarakat sudah mengembangkan pariwisata desanya melalui penyediaan homestay. Namun upaya ini tidak didasari dengan pemetaan yang jelas oleh pemerintah desa. Selama ini pemerintah desa hanya fokus pada homestay dan event kirab pusaka agung. Walaupun kegiatan tersebut dapat menarik wisatawan dalam jumlah yang besar, namun acara ini hanya dilaksanakan setiap satu tahun sekali. Oleh karena itu, pemerintah desa harus mencari alternatif pariwisata lainnya dalam mengembangkan pariwisatanya guna menghasilkan pendapatan masyarakat yang berkelanjutan.

Selain itu, pembentukan POKDARWIS Lwang Wentar merupakan bagian dari sarana penyokongan pariwisata desa, yang bertujuan untuk memberikan bimbingan dan dukungan dalam menjalankan peran dan tanggungjawab pengembangan pariwisata desa. Pembentukan POKDARWIS Lwang Wentar merupakan respon wacana pengoptimalan pariwisata dari pemerintah Kabupaten Blitar. Hal ini direspon secara proaktif oleh pemerintah desa Sawentar dengan membentuk event kirab budaya yang ditetapkan sebagai salah satu destinasi kegiatan wisata di Desa Sawentar.

Gotong royong yang mendasar pada masyarakat telah mempertahankan beberapa tradisi yang saat ini sudah tidak bisa ditemukan di Kabupaten Blitar, seperti tiban, kirab pusaka, baritan dan kirim leluhur dusun. Namun, Predikat gotong royong yang disematkan terlalu dini menyebabkan masyarakat dan pemerintah desa Sawentar tidak siap untuk melaksanakan segala tanggung jawab guna mengoptimalkan keunikan tradisi budaya gotong royong tersebut. Ketidaksiapan ini terlihat dari promosi (melalui media cetak dan media sosial) tradisi gotong royong yang tidak optimal, baik oleh pemerintah desa maupun POKDARWIS Lwang Wentar. Hal tersebut menyebabkan terbatasnya pengetahuan konsumen tentang destinasi wisata di Desa Sawentar yang hanya berupa kegiatan kirab pusaka.

Strategi pengembangan pariwisata yang dilakukan oleh pemerintah Desa Sawentar melalui pengembangan event atau kegiatan budaya dianggap sebagai upaya pemberdayaan masyarakat melalui perdagangan. Melalui kegiatan budaya tersebut diharapkan masyarakat dapat secara proaktif dan mandiri mengembangkan dan mempromosikan hasil usaha kreatifnya. Pemerintah Desa Sawentar juga mengundang berbagai media (cetak maupun televisi) seperti Trans7 untuk mendongkrak promosi kegiatan budaya kirab pusaka. Hal ini dimaksudkan 
untuk memberikan informasi yang lebih luas kepada khalayak umum tentang pariwisata budaya yang ada di desa Sawentar dengan berbagai kearifan lokal yang beragam, baik dari acara budaya, makanan khas, serta keberagaman masyarakatnya.

Fokus kegiatan POKDARWIS Lwang Wentar lebih dominan atau perhatian pada penyediaan dan pengelolaan homestay. Pengelolaan homestay ini tergolong cukup memenuhi standar kenyamanan, baik dari sisi makanan, tempat tidur, kebersihan, keramahan pemilik rumah, serta harga yang terjangkau. Makanan yang disajikan berupa makanan yang dikonsumsi sehari-hari oleh pemilik rumah, seperti pecel, sayur nangka, sayur rebung, dan masakan tradisional yang lainnya. Rata-rata tamu homestay ini menemukan penginapan di desa Sawentar melalui internet. Selama empat tahun berjalannya kegiatan POKDARWIS Lwang Wentar ini, pengunjung homestay cukup baik, sebab para tamu (yang umumnya berasal dari kota-kota besar seperti Jakarta dan Surabaya) lebih meminati penginapan yang kental dengan suasana pedesaan atau tradisional.

Berbagai homestay yang ada di Desa Sawentar memanfaatkan rumah penduduk setempat. Walau demikian, hal tersebut dapat dikategorikan sebagai bagian dari pemberdayaan masyarakat. Namun konsekuensinya adalah bahwa dampak (berupa keuntungan ekonomi) hanya dapat dirasakan oleh individu atau keluarga yang memiliki fasilitas penginapan tersebut, dan tidak menyeluruh untuk masyarakat Desa Sawentar. Oleh karena itu, masyarakat yang antusias dalam kegiatan periwisata ini hanya beberapa orang saja, serta memungkinkan timbulnya kecemburuan dan konflik sosial di antara masyarakat.

\section{2) Hambatan dalam Pengembangan Pariwisata di Desa Sawentar}

Dari penelitian yang dilakukan, diketahui bahwa terdapat empat hambatan utama dalam pengembangan pariwisata di Desa Sawentar sebagai berikut.

Pertama, tidak ada pemetaan potensi pariwisata strategis.

Sejak tahun 2016, pemetaan potensi pariwisata strategis Desa Sawentar belum pernah dilakukan. Fokus penataan pariwisata yang dilakukan oleh pemerintah desa selama ini berkisar pada penataan fasilitas umum, seperti pasar, pengaspalan jalan sekitar candi, dan fasilitas lainnya. Karena itu, ketika dicanangkan sebagai desa wisata budaya, pengelolaan pariwisata di Desa Sawentar cenderung tidak berkembang, baik dalam hal pengorganisasian maupun pengembangannya. Hal ini dapat terlihat dari tidak adanya inisiatif dan upaya untuk mensinergikan keberagaman potensi pariwisata yang ada di Desa Sawentar dalam kemasan paket-paket wisata. Dengan kata lain, masing-masing kegiatan pariwisata saling terpisah dan berdiri sendiri sehingga hasil yang diperoleh pun tidak bersifat menyeluruh (tanpa efek kumulatif).

Selain pihak pemerintah desa, POKDARWIS Lwang Wentar juga tidak melakukan pemetaan potensi pariwisata strategis. Hal ini berakar dalam keterbatasan paradigma tentang potensi pariwisata, di mana potensi pariwisata hanya dianggap sebatas yang mempunyai nilai budaya sebagai warisan nenek moyang, seperti candi, batik dan kirab budaya, yang dikenal dengan istilah nguringuri budhoyo. Paradigma yang demikian menyebabkan terabaikannya potensi pariwisata yang meluas sesuai dengan kearifan lokal dan aktivitas harian masyarakat yang sebenarnya menjanjikan sebagai produk pariwisata yang dinamis. Padahal, potensi pengembangan ini telah diamanatkan oleh Dinas 
Pariwasata Kabupaten Blitar untuk dikembangkan di Desa Sawentar, sehingga memungkinkan munculnya paket wisata yang memadukan wahana pariwisata dengan konteks kehidupan masyarakat.

\section{Kedua, tidak adanya pembinaan organisasi.}

Pada saat awal pembentukan POKDARWIS Lwang Wentar tidak ada pembekalan khusus tentang posisi dan peran organisasi.. Pemerintah desa mengakui ketiadaan pembekalan secara khusus tersebut, karena alasan sumber daya manusia lokal yang kurang untuk membina secara berkala. Bahkan, pemerintah desa dan POKDARWIS sendiri tidak ada dalam hal komunikasinya. Event kirab tradisi (grebeg Lwang Wentar) yang disponsori pemerintah desa pun pada prosesnya tidak murni diinisiasi bersama POKDARWIS Lwang Wentar, tetapi lebih kepada organisasi tertentu, baik dalam hal konsep maupun pelaksanaannya.

Pemilihan ketua POKDARWIS ini dilandasi karena adanya kekerabatan dengan perangkat desa. Walau demikian, POKDARWIS Lwang Wentar tidak mendapatkan keistimewaan tertentu, bahkan dalam hal pendampingan sekalipun. Penunjukan ketua secara aklamasi oleh pemerintah desa dilandasi pada pertimbangan bahwa ketua POKDARWIS Lwang Wentar merupakan orang yang akif dalam kegiatan kebudayaan, seperti macapat, jelajah situs budaya, dan pelajar tradisi bahasa Jawi Kuno. Faktor-faktor tersebut dirasa sudah cukup untuk menjadikannya sebagai ketua, tanpa memandang kualitas atau kapasitas yang dimiliki dalam hal pengembangan pariwisata yang strategis dan visioner.

Ketiadaan pembekalan tentang keorganisasian juga menyebabkan komunikasi antara POKDARWIS Lwang Wentar dengan berbagai mitra kerja lainnya terhambat. POKDARWIS Lwang Wentar juga enggan untuk mempelajari politik organisasi, sehingga kemitraan yang ada sangat terbatas, sempit dan tidak berkembang. Komunikasi tersebut menjadi tersendat karena kurangnya pengetahuan para pengurus dan anggota POKDARWIS Lwang Wentar tentang visi dan misi, cakupan, wewenang serta peran organisasi. Selain itu, alur komunikasi dalam hal pendanaan kegiatan organisasi pun tidak dipahami secara baik, sehingga laporan laporan keuangan tahunan selalu berujung pada timbulnya prasangka buruk.

\section{Ketiga, Kurangnya Alur Komunikasi Dengan Mitra Kerja.}

Kurangnya alur komunikasi ini disebabkan oleh pihak POKDARWIS Lwang Wentar yang tidak mengetahui organisasi mana saja yang seharusnya dijadikan mitra. Padahal terdapat beberapa potensi mitra kerja strategis untuk pembangunan pariwisata di Desa Sawentar, seperti KIM, Pemuda NU (Nahdlatul Ulama), Lembaga Adat Lwang Wentar, dan Kampung 1001 Tanaman. Selama ini komunikasi yang terjalin lebih dilakukan secara personal, baik dengan pihak pemerintah desa, karang taruna dan paguyuban tiban.

Selain itu pihak POKDARWIS pun kurang menjalin komunikasi dengan mitra yang berpotensi untuk membangun pariwisata dan pemberdayaan, terutama pada kepala urusan perencanaan dalam struktur pemerintah Desa Sawentar. Komunikasi ini sangat penting karena program-program yang dilaksanakan oleh POKDARWIS Lwang Wentar merupakan bagian dari program utama pemerintah desa dalam pemberdayaan masyarakat.

Secara internal, kurangnya komunikasi ini juga menyebabkan open recruitment anggota POKDARWIS Lwang Wentar yang terbatas, serta program 
kegiatan yang dilaksanakan secara informal tanpa berpatokan pada prosedur yang profesional dan tanpa garis koordinasi yang teratur. Selain menimbulkan kesalah pahaman, kurangnya komunikasi ini juga mengakibatkan terabaikannya berbagai peluang alternatif kreatif dan sumber daya yang dapat diperoleh dan dimanfaatkan untuk pengembangan pariwisata di Desa Sawentar, seperti studi banding, pemetaan dan simulasi pariwisata serta anggaran dana desa yang tersedia.

\section{Keempat, Konflik Antar Organisasi.}

Salah satu hambatan yang terjadi dalam pengembangan pariwisata pada desa Sawentar adalah kesalahpahaman antara organisasi POKDARWIS Lwang Wentar dengan Karang Taruna Desa Sawentar. Kesalahpahaman ini dipicu oleh ego organisasi yang kemudian menyebar dan berkepanjangan, hingga berkembang menjadi persaingan dan konflik antar organisasi.

Konflik antar organisasi yang terjadi di Sawentar berawal dari proses berdirinya POKDARWIS Lwang Wentar. Pada saat pembentukannya, beberapa anggota Karang Taruna (yang berasal dari Dusun Centong, di mana terdapat Candi Sawentar) yang mengundurkan diri dari organisasi karena ingin menjadi pengurus tetap di POKDARWIS Lwang Wentar. Pengunduran diri dan perpindahan organisasi ini terjadi akibat adanya kesalahpahaman bahwa POKDARWIS Lwang Wentar dibentuk oleh pemerintah Desa Sawentar untuk menjadi pengelola pariwasata Candi Sawentar semata, dan bukan sebagai kelompok penggerak pengembangan potensi pariwisata di Desa Sawentar yang menyeluruh. Kejadian tersebut disusul dengan saling kritik dan saling serang di media sosial (facebook maupun Whatsapp), yang kemudian juga berkembang menjadi konflik, dendam dan permusuhan antar pribadi.

Konflik antar organisasi tersebut menguat pada pelaksanaan event kirab pusaka budaya, di mana kedua organisasi tersebut menjadi mitra kerja pelaksana. Para anggota POKDARWIS Lwang Wentar menganggap bahwa ide yang ditawarkan selalu ditolak, dan peran yang dijalankan pada hari pelaksanaan event hanya sebatas sebagai tukang jaga parkir dan pengatur lalu lintas. Hal ini menimbulkan ketersingungan dan dendam antar organisasi, sehingga kerja kemitraan menjadi terhambat dan tidak efektif, sebab selalu diwarnai dengan perebutan peran utama dan dominasi.

Pemerintah Desa Sawentar memang telah berupaya melakukan mediasi guna mendamaikan kedua organisasi ini. Akan tetapi idealisme dan ego organisasi telah cukup kuat mengakar dan diteruskan pada generasi-generasi selanjutnya. Selain itu, upaya pembinaan yang dilakukan pemerintah desa juga hanya terbatas pada nasehat, tanpa adanya upaya yang berkelanjutan untuk menata dan memperbaiki kembali relasi kemintraan yang kondusif antara kedua organisasi tersebut.

\section{3) Model Pengembangan Pariwisata Berbasis Masyarakat}

Model pemberdayaan masyarakat untuk pengembangan pariwisata di Desa Sawentar yang ditawarkan adalah model Wisata Edukasi. Model ini dipilih karena dianggap sebagai alternatif potensi strategis yang perlu dimanfaatkan dan dikembangkan lebih lanjut. Pada penyusunan model ini tentunya menggunakan rumus 4D Define, Design, Develop, dan Disseminate (Thiagarajan, 1974). Pada gambaran penyusunan model tersebut dapat ditentukan sebuah alur pengembangan pariwisata di Desa Sawerntar. Pertama peneliti melihat fakta-fakta 
dan gambaran lapangan bahwa terjebak dalam pemikiran atau makna budaya serta alur komunikasi. Hal ini dikarenakan pemikiran terjebak konsep budaya, konsep budaya yang mereka pahami adalah budaya yang mempertahankan tradisi peninggalan nenek moyang. Jika ditelusuri makna budaya bukanlah hanya tradisi melainkan mencakup sebuah peradaban manusia itu sendiri seperti kehidupan sosialnya.

Upaya mencegah terjadinya pemikiran tersebut, perlu diadakan focus group discussion (FGD). Kegiatan ini ditujukan untuk menyatukan pikiran serta mengumpulkan para pemangku kepentingan seperti perangkat desa, pelaku usaha khususnya yang terkait dengan bidang wisata, pemilik kesenian, tetua adat, dinas terkait, LSM atau peneliti, serta organisasi karang taruna. Pada forum tersebut diberikan ruang untuk bertukar pikiran serta menjalin komunikasi satu pintu agar terciuptanya sebuah kemitraan dalam membangun pariwisata yang berbasis masyarakat. Kedua proses perancangan pada hasil FGD (focus group discussion) tentu merumuskan sebuah rancangan yang diuji cobakan, pada proses tersebut muncul ide wisata edukasi yang menunjukan kondisi sosial-budaya masyarakat Desa Sawentar. Para calon wisatawan diajak berkeliling desa Sawentar menggunakan kereta kelinci (kereta mini) untuk mengunjungi UMKM batik, jajanan tradisional, dan pembuatan batu bata. Tidak hanya UMKM saja melainkan calon wisatawan diajak mempelajari kesenian yang ada di Desa Sawentar yaitu jaranan (kuda lumping) karawitan (gamelan) pranoto coro (tata cara upacara pernikahan Jawa). Konsep ini diuji cobakan pada lapngan dengan peserta anakanak sekolah dasar pemilihan ini dikarenakan konsep wisata yang di berikan adalah edukasi serta menanamkan pentingnya mengenal kehidupan bermasyarakat.

Ketiga pengembangan, setelah sumber daya disusun serta di uji cobakan kemudian pada tahap pengembang inilah ide-ide kreatif mulai bermunculan. Seperti penyambutan wisatawan dengan cara welcome drink memberikan minuman tradisional berupa jamu seperti beras kencur, asam kunyit, atau temulawak. Pada setiap wahana diberikan cinderamata yang menarik berupa khas Desa Sawentar, atau pada akhir wahana dibuatkan permainan tradisional. Keempat penyebaran, setelah tersusun secara rapi pemasaran produk adalah garda terdepan sebab pemasaran ini merupakan salah satu penentu dari masa depan pariwisata tersebut diminati atau tidak. Pemasaran tersebut dilakukan dengan door to door dengan memberikan brosur, melalui media sosial, mengundang komunitas untuk memperkenalkan wisata tersebut seperti google local giuide, serta aktif dalam kegiatan atau festival yang di buat oleh pemerintah daerah.

\section{PEMBAHASAN}

Pemberdayaan masyarakat dilakukan dengan penerapan fokus dan pendekatan yang sesuai dengan potensi yang ada dalam masyarakat. Hal ini mencakup di dalamnya serangkaian prinsip, teknik dan praktik yang mampu mengembangkan potensi menjadi kekuatan melalui program pemberdayaan yang terstruktur. Pemberdayaan yang efektif bukan berlandaskan pada adanya kesempatan semata, tetapi merupakan hasil dari penentuan pilihan kegiatan prioritas, bukan dari hasil trial and error, tetapi dari akibat perencanaan yang baik (Mardikanto, 2017). 
Dapat dilihat bahwa dalam perspektif konsep pemberdayaan masyarakat upaya dalam hal pengelolaan pariwisata budaya oleh pemerintah Desa Sawentar telah mencakup beberapa elemen utama pemberdayaan masyarakat yang dapat dilakukan dengan konsep 5P yakni pemungkinan, penguatan, penyokongan dan perlindungan (Suharto, 2005). Pertama, Pemungkinan, merupakan suasana yang memungkinkan potensi masyarakat berkembang optimal, dengan membebaskan masyarakat dari batas-batas kultural dan struktural yang menghambat. Kedua, Penguatan, bertujuan untuk memberikan landasan pengetahuan, kemampuan dan kepercayaan diri masyarakat dalam memcahkan masalah dan memenuhi kebutuhan-kebutuhannya secara mandiri. Ketiga, Perlindungan, guna melindungi masyarakat terutama kelompok-kelompok lemah agar tidak tertindas oleh kelompok kuat, serta menghindari terjadinya persaingan-persaingan yang tidak seimbang, dominatif dan diskriminatif. Keempat, Penyokongan, merupakan bentuk bimbingan dan dukungan terhadap masyarakat agar dapat menjalankan peranan dan tanggung jawab kehidupannya, serta terjatuh ke dalam keadaan dan sebuah posisi yang semakin terpinggirkan. Kelima, Pemeliharaan, yakni menjaga kondisi yang kondusif agar terjadi keseimbangan distribusi kekuasaan dengan macam-macam kelompok dalam masyarakat, guna mempertahankan keselarasan dan keseimbangan yang memungkinkan setiap individu mendapatkan kesempatan berusaha.

Elemen pemungkinan dapat dilihat dalam bentuk pemanfaatan kebiasaan hidup masyarakat yang tradisional sebagai salah satu jualan pariwisata. Elemen penguatan dapat dilihat dalam kegiatan edukasi pariwisata dan pelatihan profesinalitas pelayanan guna menjamin kenyamanan konsumen dan memperoleh manfaat ekonomis. Elemen penyokongan dapat dilihat dalam pemebentukan POKDARWIS Lwang Wentar sebagai bentuk respon untuk pengoptimalan potensi pariwisata di Desa Sawentar. Elemen perlindungan dapat dilihat dalam bentuk kehadiran dan geliat industri kreatif UMKM dan homestay yang dilaksanakan oleh masyarakat setempat.

Sementara itu, elemen pemeliharaan, sebagai elemen terakhir dari konsep pemberdayaan 5P tampak belum diperhatikan secara serius melalui penataan peluang pariwisata yang menyeluruh, sinergis dan bukan bersifat individual. Hal ini kemudian membuka peluang bagi munculnya kecemburuan sosial, kompetisi atau persaingan tidak sehat, bahkan konflik di antara masyarakat. Selain itu, intervensi pemerintah tampak tidak dilakukan dengan perencanaan yang terprogram secara baik (mulai dari perencanaan hingga evaluasi), tidak cukup proaktif untuk menggali dan mengembangkan keberagaman potensi pariwisata yang ada, kurang melibatkan kelompok-kelompok profesional serta tidak didukung dengan penganggaran yang proporsional guna memungkinkan pengembangan kegiatan-kegiatan usaha dan meningkatkan posisi tawar masyarakat.

Konsep pemberdayaan masyarakat 5P ini berfokus pada cara pendekatan pemberdayaan dengan demikian, implementasinya dapat dilakukan dengan memanfaatkan keunikan kondisi dan sumber daya yang ada di setiap tempat (Suharto, 2009). Dalam hal pemberdayaan masyarakat untuk mengembangkan potensi pariwisata di Desa Sawentar, pendekatan 5P tersebut dapat dilakukan dengan menggunakan kebiasaan atau budaya masyarakat setempat, yang dikenal dengan istilah nandur srawung gayeng anteng. Kebiasaan budaya ini 
memampukan munculnya gagasan, inisiatif dan gerakan proaktif dari masyarakat dalam iklim kesetaraan dan persaudaraan untuk mendorong wacana dan mengimplementasikan pengembangan potensi pariwisata desa dalam semangat gotong royong. Dengan pendekatan kebiasaan budaya tersebut, geliat pengembangan potensi pariwisata di Desa Sawentar menjadi bersifat bottom-up, dengan pemaknaan yang lebih mengakar dalam diri masyarakat.

Berdasarkan deskripsi pada bagian sebelumnya tampak bahwa pengembangan pariwisata berbasis pemberdayaan masyarakat di Desa Sawentar berada pada tahap informing (menginformasikan), yang dilakukan melalui event pariwisata budaya Grebek Lwang Wentar. Hal inilah menyebabkan perkembangan wisata di Desa Sawentar menjadi terhambat, sebab masih terdapat banyak potensi pariwisata yang dapat diolah menjadi wahana wisata edukasi dan budaya namun belum tersentuh secara serius.

Dalam teori partisipasi masyarakat (Arnstein, 1969) terdapat sebuah tingkatan Manipulation (manipulasi), pemerintah desa mendidik atau memilih sebagian dari masyarakat untuk menampung aspirasi dari masyarakat, namun masyarakat sama sekali tidak mengetahui hal tersebut. Dalam Therapy (pemulihan), pemerintah menyampaikan visi dan misi program kerja kepada perwakilan masyarakat dan perwakilan masyarakat hanya mendengarkan. Dalam Informing (menginformasikan), pemerintah desa menyampaikan visi misi dan program kerja terhadap masyarakat, masyarakat hanya bisa menerima informasi dan tidak terjadi umpan balik. Dalam Consultation (mengkonsultasikan), mulai terjadi dialog antara kedua belah pihak tentang berbagai persoalaan yang ada, di mana saran dan kritik ditampung, namun keputusan akhir merupakan wewenang pemerintah desa. Dalam Placation (mendiamkan), pemerintah desa mendengarkan dan menerima berbagai kritk dan saran yang disampaikan masyarakat, namun pemerintah desa tetap pada rencana awal. Dalam Partnership (bekerjasama), pemerintah desa memberlakukan masyarakat sebagai mitra kerja untuk bersamasama bekerja dalam menyusun dan melaksanakan program kerja. Dalam Delegated Power (mendelegasikan kewenangan), pemerintah desa mendelegasikan kewenangan kepada masyarakat untuk mengambil keputusan. Dalam Citizen Control (kontrol publik), kontrol masyarakat terhadap kinerja pemerintah desa sangat kuat, termasuk mengevaluasi kinerja pemerintah desanya.

Kedelapan anak tangga diatas mengkelompokkan tiga kelompok partispasi. Pertama, non-participation (tidak berpartisipasi), yakni berupa manipulasi dan terapi. Di sini pemerintah desa menghilangkan partisipasi. Artinya disini hal-hal yang dilakukan dalam mencari model pemberdayaan adalah mengobservasi lapangan atau mewawancarai beberapa individu untuk mencari tau permasalahan serta menampung aspirasi masyarakat. Kedua, tokenism (perlakuan negatif), yakni berupa menginformasikan, mengkonsultasikan dan mendiamkan. Di sini masyarakat tidak dihalang-halangi bahkan diberikan ruang untuk berpartisipasi. Akan tetapi rencana untuk melaksanakan program tetap dalam rencana semula. Ketiga, citizen power (kekuatan masyarakat), yakni berupa kerjasama, pendelegasian wewenang dan kontrol publik. Pada tahapan inilah partisipasi masyarakat tercipta secara ideal, di mana masyarakat diberikan keleluasaan untuk berpartisipasi, menentukan masa depan desanya dan mampu mengontrol kinerja pemerintah desa. 
Model pengembangan pariwisata berbasis pemberdayaan masyarakat di Desa Sawentar yang terjadi selama ini juga menggunakan konsep pariwisata edukatif. Namun dalam prakteknya, pengelolaanya tidak mengembangkan berbagai potensi yang ada, serta tidak mempelajari setiap karakteristik destinasinya. Oleh karena itu, model yang ditawarkan melalui penelitian ini adalah model pariwisata edukatif yang memanfaatkan bentuk kehidupan seharihari masyarakat Desa Sawentar, yang merujuk pada kegiatan industri kreatif serta kehiupan sosial-budaya masyarakat. Selain itu, pengembangan model pariwisata edukatif ini perlu dilakukan dalam bentuk paket wisata budaya, dengan mempelajari dan mengembangkan karakteristik masing-masing destinasi secara optimal. Dengan demikian, pemandu wisata dapat menguasai destinasi yang ditawarkan, sehingga dapat tercipta pola kemitraan serta kerjasama antar masyarakat dan antar kelompok organisasi yang ada di Desa Sawentar.

Kemitraan dan kerjasama ini dapat dilakukan dengan membuat sistem kerja masyarakat sebagai pemandu wisata kolaboratif yang terdiri dari pemandu utama dan asisten pemandu. Pemandu utama adalah seseorang yang menguasai salah satu destinasi, sementara asisten pemandu adalah orang mengkoordinir wisatawan serta membantu tugas-tugas dari pemandu utama. Untuk tujuan ini dapat dilakukan dengan komposisi homogen (masyarakat dengan masyarakat, kelompok dengan kelompok) ataupun heterogen (masyarakat dengan kelompok). Selain itu, model kemitraan tersebut dapat diaplikasikan pula pada kerjasama bisnis masyarakat yang saling menguntungkan, dengan tetap berlandaskan pada prinsip pemberdayaan masyarakat guna memperkuat kelompok masyarakat yang lemah untuk mampu menjadi mandiri.

Pola kemitraan itu sendiri meliputi kemitraan destinasi pariwisata dan kemitraan promosi pariwisata. Kemitraan secara destinasi pariwisata dilakukan dengan mengajak, memberikan pemahaman serta membuka ruang bagi masyarakat pelaku industri kreatif untuk menjadikan tempat dan kegiatan usahanya sebagai destinasi wisata edukatif di Desa Sawentar. Dalam hal ini, setiap bahan, perlatan, proses pengerjaan serta makna yang tersirat dalam setiap produk industri kreatif tersebut dijadikan sebagai materi edukasi kepada para konsumen atau pengunjung. Hal tersebut di satu sisi berdampak pada warisan tradisi budaya yang tetap dilestarikan dan disosialisasikan, serta di sisi lain menjadi sumber penghasilan ekonomi tersendiri. Dengan demikian, diharapkan seluruh masyarakat akan terdorong untuk ikut berpartisipasi secara aktif dalam membangun pariwisata di Desa Sawentar.

Sementara itu, kemitraan secara promosi pariwisata, dilakukan dengan bekerja sama dengan beberapa komunitas google local guide untuk memberikan review mengenai tempat, kegiatan dan jenis pariwisata yang ada di Desa Sawentar. Kerjasama tersebut secara perlahan-lahan perlu dikembangkan juga hingga mencapai bentuk transfer pengetahuan dan keterampilan, sehingga kemudian akan ada individu atau komunitas google local guide yang mandiri di Desa Sawentar. Penekanan pada google local guide tersebut dilandasi oleh fenomena penggunaan gawai yang sangat tinggi, serta pengembangan aplikasi dan fitur-fitur menarik yang tersedia dalam perangkat gawai. Hal-hal tersebut merupakan potensi yang tersedia untuk dimanfaatkan secara optimal sebagai sarana promosi yang tepat dalam bisnis pariwisata.

876 BRILIANT: Jurnal Riset dan Konseptual

Volume 5 Nomor 4, November 2020 
Model pariwisata edukasi memungkinkan terbangunnya jembatan ide dan gagasan untuk mentransfer paradigma yang strategis, memanfaatkan berbagai potensi yang ada, merancang kerja yang efektif dan efisien, mendorong partisipasi aktif masyarakat dan melakukan gerakan pengembangan pariwisata yang bersifat bottom-up. Dengan demikian, pemberdayaan masyarakat untuk pengembangan pariwisata dapat mencapai sasarannya, yakni terwujudnya geliat pariwisata di Desa Sawentar yang bersumber dari inisiatif dan gerakan proaktif masyarakat, dilakukan dalam pola kemitraan dan kerjasama kolaboratif oleh masyarakat serta membawa dampat positif untuk masyarakat Desa Sawentar.

\section{KESIMPULAN}

Berdasarkan deskripsi di atas, kesimpulan umum penelitian ini adalah bahwa pengelolaan pariwisata di Desa Sawentar belum berjalan secara optimal, dan karena itu diperlukan pengembangan ke depannya. Selama ini, pengelolaan pariwisata oleh pemerintah Desa Sawentar dilakukan melalui peletarian tradisi budaya dan pelatihan pengelolaan homestay. Keterbatasan tersebut diperparah dengan sejumlah hambatan utama dalam pelaksanan pengelolaan pariwisata di Desa Sawentar yakni berupata tidak ada pemetaan potensi pariwisata strategis, tidak adanya pembinaan organisasi POKDARWIS Lwang Wentar, kurangnya alur komunikasi dengan mitra kerja, serta adanya konflik antar organisasi. Berdasarkan kondisi yang demikian, serta dengan merujuk pada teori yang digunakan dalam penelitian ini, maka model pengembangan pariwisata berbasis masyarakat di Desa Sawentar yang ditawarkan yakni melalui pengembangan pariwisata edukasi. Model ini diharapkan mampu mengintegrasikan pengelolaan pariwisata berbasis pemberdayaan masyarakat serta mendorong partisipasi aktif masyarakat Desa Sawentar.

\section{SARAN}

Berdasarkan kesimpulan di atas, penelitian ini menyarankan kajian lebih lanjut terhadap model wisata edukatif yang dirumuskan melalui ujicoba ulang efektivitasnya, sehingga dapat dikembang model yang sesuai dengan kondisi pada lapangan. Dengan pengujian dan kajian lebih lanjut, diharapkan model ini dapat dijadikan sebagai sebuah acuan pengembangan pariwisata berbasis masyarakat, khususnya untuk para penggiat, stakeholder, serta pemerintah desa Sawentar dalam merumuskan model pariwisata yang sesuai dengan kondisi lingkungan dan masyarakat.

\section{DAFTAR RUJUKAN}

Arnstein, Sherry R. 1969. A Ladder of Citizen Participation. Journal of the American Institute of Planners. Vol. 35, No. 4, pp. 216-224.

Damanik, Prof.Dr.Phil. Janinton. 2017. Priwisata Indonesia antara peluang dan tantangan. Yogyakarta: Pustaka Pelajar.

Friedman, John. 1992. Empowerment The Politics of Alternative Development. Blackwell Publishers, Cambridge, USA.

Mardikanto, Prof. Dr. Ir. Totok. 2017. Pemberdayaan Masyarakat Dalam Perspektif Kebijakan Publik. Bandung: Alfabeta 
Miles, Matthew B., Huberman, Michael A., \& Saldana, Jhonny. 2014. Qualitative Data Anakysis: A Methods Sourcebook ( ${ }^{\text {rd }}$ ed.) Arizona State University: SAGE Publication, Inc.

Thiagrajan, S., Semmel., D.S \& Semmel., M.I. 1974. Instructional Developmet For Training Teachers Of Expectional Children. Minneapolis: Leadership Training Institute University Of Minnesota.

Suharto E. 2005. Membangun Masyarakat Memberdayakan Rakyat. Kajian S trategi Pembangunan Kesejahteraan Sosial dan Pekerjaan Sosial. Bandu ng: PT Refika Aditama.

2009. Membangun Masyarakat Memberdayakan Rakyat. Bandung: Refika Aditama, Cetakan Ketiga. 